\title{
THE ROLE PLAYING GAME (RPG) AS A PEDAGOGICAL STRATEGY IN THE TRAINING OF THE NURSE: AN EXPERIENCE REPORT ON THE CREATION OF A GAME ${ }^{1}$
}

\author{
Amanda Nathale Soares², Maria Flávia Gazzinelli, Vânia de Souza, Lucas Henrique Lobato Araújo ${ }^{5}$
}

\begin{abstract}
${ }^{1}$ This article is an excerpt from the dissertation - Role Playing Game (RPG): the elaboration and evaluation of a pedagogical strategy for the critical and autonomous training of the nurse, presented to the Postgraduate Program in Nursing of the School of Nursing of the Universidade Federal de Minas Gerais (UFMG), in 2013.

${ }^{2}$ Doctoral student of the Postgraduate Program in Nursing of the School of Nursing of the UFMG. Belo Horizonte, Minas Gerais, Brazil. E-mail: amandanathale0708@gmail.com

${ }^{3}$ Ph.D. in Nursing. Associate Professor of the Department of Applied Nursing, School of Nursing, UFMG. Belo Horizonte, Minas Gerais, Brazil. E-mail: flaviagazzinelli@yahoo.com.br

${ }^{4}$ Post-Ph.D. Adjunct Professor of the Department of Mother-and-Child Nursing and Public Health, School of Nursing, UFMG. Belo Horizonte, Minas Gerais, Brazil. E-mail: vaniaxsouza@yahoo.com.br

${ }^{5}$ Doctoral student of the Postgraduate Program in Nursing of the School of Nursing, UFMG. Belo Horizonte, Minas Gerais, Brazil. E-mail: lucaslobato87@gmail.com
\end{abstract}

\begin{abstract}
This is an experience report on the creation of a Role Playing Game used as a pedagogical strategy for promoting the development of autonomy and critical-reflexive thinking among undergraduate students of Nursing during their training. The game's creation took place in the School of Nursing of the Federal University of Minas Gerais, between November 2011 - March 2012, involving four stages: definition of the game design; creation of the game's prototype; and evaluation of the game's dynamic by players of Role Playing Games; and preparation of the 'masters'. The game was created with the aim of providing the students of the Nursing Course with metaphorical experience of problem-situations corresponding to the main scenarios of professional activity. It is believed that the game prepared constitutes a pedagogical strategy in which the students engage and become involved in their process of thinking, of elaborating new meanings, of knowing and of acting.
\end{abstract}

DESCRIPTORS: Education nursing. Teaching materials. Play and playthings. Health human resource training.

\section{ROLE PLAYING GAME (RPG) COMO ESTRATÉGIA PEDAGÓGICA NA FORMAÇÃO DO ENFERMEIRO: RELATO DA EXPERIÊNCIA DE CRIAÇÃO DO JOGO}

RESUMO: Trata-se de um relato de experiência sobre a criação de um jogo de Role Playing Game utilizado como estratégia pedagógica para favorecer aos alunos de graduação em enfermagem o desenvolvimento da autonomia e do pensamento crítico-reflexivo em sua formação. A criação do jogo ocorreu na Escola de Enfermagem da Universidade Federal de Minas Gerais, entre novembro de 2011 e março de 2012, envolvendo quatro etapas: definição do desenho do jogo; criação do protótipo do jogo; avaliação da dinâmica do jogo por jogadores de Role Playing Game; e preparo dos mestres. O jogo foi criado com o intuito de proporcionar aos alunos do Curso de Enfermagem a vivência metafórica de situações-problema correspondentes aos principais cenários de atuação profissional. Acredita-se que o jogo elaborado tem se constituído em uma estratégia pedagógica em que os alunos se implicam e são implicados em seu processo de pensar, de elaborar novos sentidos, de conhecer e de agir.

DESCRITORES: Educação em enfermagem. Materiais de ensino. Jogos e brinquedos. Capacitação de recursos humanos em saúde.

\section{JUEGO DE ROL (RPG) COMO ESTRATEGIA DE ENSEÑANZA EN EDUCACIÓN DE ENFERMERÍA: INFORME DE LA EXPERIENCIA DE CREAR JOGO}

RESUMEN: Este es un relato de experiencia en la creación de un juego de Role Playing Game utilizado como una estrategia pedagógica para animar a los estudiantes de pregrado en Enfermería autonomía en desarrollo y el pensamiento crítico-reflexivo en su formación. La creación del juego se produjo en la Escuela de Enfermería de la Universidad Federal de Minas Gerais, entre noviembre de 2011 y marzo de 2012, que implica cuatro pasos: definición de diseño del juego; creación del prototipo del juego; la evaluación de la dinámica del juego para los jugadores de rol; y la preparación de los maestros. El juego fue creado con el objetivo de animar a los estudiantes de enfermería experiencia metafórica de situaciones problemáticas que corresponden a los principales escenarios de trabajo profesional. Se cree que el juego elaborado se ha constituido como una estrategia en la que los estudiantes se involucran y participan en el proceso de pensar, desarrollar nuevas formas de conocer y actuar.

DESCRIPTORES: Educación en enfermería. Materiales de enseñanza. Juego e implementos de juego. Capacitación de recursos humanos en salud. 


\section{INTRODUCTION}

In Brazil, based on the National Curricular Guidelines for Undergraduate Courses in Nursing, instituted in 2001, institutions teaching nursing are passing through a period of restructuring their pedagogical projects, the aim being to promote the training of nurses who are more critical, reflexive and autonomous. ${ }^{1}$

In this restructuring, the teaching and learning strategies used in the training of the nurse stand out as one of the fundamental aspects to be (re) signified. This is because, in the undergraduate training in nursing, traditional pedagogical strategies predominate, centered on the professor's exposition and on the memorization of information by the students. These traditional strategies, in general, lead to a dissociation between the theoretical knowledge which has been passively received by the students, and the context in which these are inserted, returning to the reproducing of the knowledge to the detriment of their criticalreflexive construction. ${ }^{2}$

It follows therefore that the pedagogical strategies must be considered from a dialogic and interactionist perspective, which calls for the student's active participation in the construction of the knowledge, and the lecturer's participation as the person who creates and offers situations which leads students to exercise problematization. When based in dialogue, in the interaction between educator and the person being educated, and in the student's active participation, the pedagogical strategies promote greater problematization of the knowledges, fostering the construction of knowledge through reflection and criticality. ${ }^{3}$

Based on this conception, it is possible to perceive that the insertion of games in the educational environment may be configured as facilitating the process of teaching and learning. Defined as a free action, experienced in a fictitious order, and situated outside everyday life, ${ }^{4}$ the game, through play and pleasure, can constitute a pedagogical strategy which is capable of favoring dialogue, the joint construction of knowledge, the creation of challenging and reflexive environments, the development of autonomy, the practicing of skills, and the better internalization of content. ${ }^{5-9}$

Considering these potentials of the use of games in the educational context, this article aims to report the experience of creating a game, in the Role Playing Game (RPG) format, used as a pedagogical strategy in nursing training.
RPGs are games of representation, defined as a cooperative activity in which a group of players, guided by a master - who coordinates and narrates the game - creates a story collectively, in the oral, written or animated form. It is an interactive narrative, episodic and participatory..$^{10}$ This format of game promotes the construction of metaphors and imaginary representations which can lead to liberty, to the encouragement of questioning, to dialogue between different knowledges, and to the exercising of fun. ${ }^{11-14}$

The creation of the RPG game, used as a pedagogical strategy, aims to promote among undergraduate students of Nursing the metaphorical experience of problem-situations which correspond to the main scenarios of professional activity. It is based on the premise that this experience can promote the development of the student's autonomy and critical-reflexive thinking in relation to her training and future professional activities.

\section{METHOD}

This is an experience report on the process of creating an RPG game used as a pedagogical strategy in nurse training.

The game was created in the School of Nursing of the Universidade Federal de Minas Gerais (EEUFMG), as a requirement of the course titled "Integration Seminar II", part of the latest version of the curriculum, implanted in 2009. This course, run interdepartmentally, is offered in the third semester of the Undergraduate Course in Nursing and integrates a set of three courses termed "Integration Seminars". In these courses, the aim is to promote integration between the contents of the courses undertaken and the experiences which lead to autonomy and critical-reflexive thinking regarding the process of training and future professional practice.

The objective of the "Integration Seminar II" course, in particular, is to integrate the content related to the following dimensions of nursing care: care provision, education, research and management. It is also to promote the exercising of skills and competences for professional practice through the RPG. Furthermore, it aims to promote the choices of the formative pathway offered on the course, of the optional courses and of the possibilities for extracurricular activities, as well as to relate these skills for professional practice with the formative pathways of the EEUFMG's undergraduate curriculum. 
The process of creating the game, undertaken between November 2011 and March 2012, involved the following stages: 1) definition of the game design; 2) creation of the game's prototype; 3) evaluation of the game's dynamic, by RPG players; and 4) preparation of the 'masters'.

The RPG players only participated in the stage evaluating the game's dynamics, the data being collected through descriptive observation, with recording of the information for later adjustment of the game. This type of observation occurs freely, although the researcher must focus on her study object. ${ }^{15}$

The study was undertaken in accordance with the requirements of Resolution 196/96, of the Brazilian Ministry of Health, ${ }^{16}$ with the approval of the Federal University of Minas Gerais' Committee for Ethics in Research involving Human Beings (04827712.3.0000.5149). The game was financed by the National Program for the Reorientation of Professional Training in Health.

\section{RESULTS}

The results are described in accordance with the four stages of the process of the creation of the game.

\section{Definition of the game's design}

Throughout, the process of the game's creation was undertaken by a multi-professional team, made up of a Ph.D. in education, who coordinated the project; a Ph.D. in health sciences, with experience in game development, the project's sub-coordinator; a psychologist, with experience in RPG games; a nurse, undertaking an M.Sc. and a specialist in education; and an undergraduate student of nursing. In addition to this, two specialists in RPGs were contracted for the creation process.

As a central axis, this was based on the idea that a game in the RPG format would represent a metaphor for the context of the undergraduate nursing student regarding the main scenarios of professional activity of the nurse. It was defined that, in order to experience these main scenarios, the students would experience - metaphorically problem-situations corresponding to four contexts of the nurse's professional practice: primary care, hospital care, management and education-research.

Subsequently, the themes and skills were defined which would make up the problem- situations of each scenario. For this definition, professionals were selected who worked in each one of the contexts established for the game. These professionals were questioned regarding the themes registered in the most frequent situations in their professional practice and in relation to the skills required most for resolving these situations. In total, approximately 10 professionals from each context were questioned, a number above which repetition of responses began to be observed. It should be highlighted that the professionals questioned worked in different services of each one of the contexts, that is, they worked in different primary healthcare centers, hospitals, management positions and institutions of higher education.

The issues defined for primary care were: domestic violence, disbelief in the health service, pregnancy in adolescence, drug addiction, food poisoning, embracement with risk classification, self-medication, home care and continuing education. The skills established for this context were charisma, focused attention, perception, dispersed care, strength, knowledge, creativity, empathy, communication, extroversion, analysis, reasoning, use of technology, versatility, abstraction and sociability.

In the hospital care, content was addressed referent to emergency attendance, abortion/ miscarriage, knowledge of the properties of the drugs, care techniques including preparation and administration of medications, beliefs and adherence to the treatment, professional ethics and continuing education. These skills corresponded to resistance, agility, focused attention, diagnosis, improvization, dispersed care, knowledge, dexterity, communication, acting under pressure, tolerance, technology use, precision, the ability to distinguish, strength, flexibility, curiosity, and ability to calculate and analyze.

In management, the topics corresponded to the deployment of professionals between departments, undertaking of professional tasks, management of material resources, interpersonal conflicts, organization of the patient throughput, organizational hierarchy, valorization of the worker, professional ethics and continuing education. The skills were empathy, versatility, charisma, sensitivity, perception, planning, focused attention, leadership, curiosity, acting under pressure, creativity, dispersed care, reasoning, organization and authority.

The scenario of education-research was composed of topics which encompassed the 
production and publication of scientific texts, achieving deadlines, the process of training and evaluating the student, and the health education. The skills defined for this area were: ability to summarize, writing, charisma, use of technology, reasoning, knowledge, organization, dexterity and focused attention.

The following stage was the creation of the game's prototype, encompassing its design, its dynamics, and the materials necessary for familiarization with the plot.

\section{The prototype game}

In the game's plot, the scenarios of primary care, hospital care, management and educationresearch are represented by four Houses, respectively named the House of the Helpers, the House of the Repairers, the House of the Supporters and the House of the Instructors. The suffix which designates these Houses gave rise to the game's name: "The Order of Ores".

The "Order of Ores" is inserted in a fictitious and atemporal story which describes the journey of a group of apprentices who must help - collectively and cooperatively - in maintaining the well-being of the population of their kingdom following a period of war.

The players are introduced to the game's plot through the narration of a prologue.

In a world called Eféryon, there were various kingdoms. Among them: Kalantar and Amyr. These two neighboring kingdoms prospered visibly. Their populations grew progressively, necessitating the expansion of their territories. It was then that the misunderstandings between these kingdoms blossomed into disputes over territory, which culminated in a war.

The kingdom of Kalantar won the war, and demarcated its domains with a wall. The kingdom of Amyr, spared dissipation by its enemy following its defeat, found itself with less territory and fewer natural resources for its survival. The King of Amyr had no alternative but to continue struggling against the kingdom of Kalantar, in a campaign that would last years.

Within its walls, Kalantar was structured so as to create better living conditions and conditions of protection for its people. Part of this structure was ensured by the Order of Ores, responsible for maintaining its population's well-being. To this end, each winter solstice, the Order of Ores recruits apprentices. At this time, a new group of apprentices was defined. Their training would be as arduous and intensive as it was enlightening, and each one would be able to find, in the adventure of all, their own path.

In the plot, the players are also prompted by phrases taken from a book called the "I-Bridge", as a strategy for assisting them in their reflections. This book is presented to the players as part of the game's storyline, as explained below.

There is, in Eféryon, a famous book called the I-Bridge, obtained - so legend says - centuries before by a powerful wizard, through a magic portal. According to some, it is a bridge to another world; in the opinion of others, to a different time. Whatever the truth may be, it cites knowledge unknown to Eféryon and its way of thinking. It is highly refined to have read this mysterious book and to quote it whenever possible. The wisdom is repeated from mouth-to-mouth, as an invitation to reflection and to understanding of the ideas. The I-Bridge cannot reveal the mystery regarding itself, but can help to unveil the reason of each one, through encouraging people, as revealed in the following phrase: "I would rather have a mind opened by wonder than one closed by belief" (Gerry Spence).

The "I-Bridge" involves certain phrases of different philosophers, such as Sartre and Aristotle, inviting the players to reflect on the experience and on its implications in their routine, as students and as future nurses. The following are examples of phrases extracted from the book "I-Bridge": "happiness is not doing what you want, but wanting what you do" (Sartre); "a wise man never says what he thinks, but always thinks everything he says" (Aristotle).

In the "Order of Ores", for the training process, it is necessary for the apprentices to pass through problem-situations in the Houses of the Helpers, the Supporters, the Repairers, and the Instructors. The training, at the end of passing through each one of the Houses, is concluded with the experiencing of challenge-situations, which aim to emphasize skills considered essential for the apprentice's training in that scenario.

This process of training is undertaken under the guidance of Tutor Ravieri (Figure 1) and the Lords of each house (Figure 2), whose role is to present the Houses to the apprentices. All these characters are represented in the game by the master. 


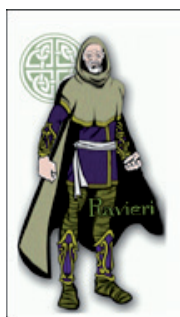

Figure 1 - Image of Tutor Ravieri, the character interpreted by the master

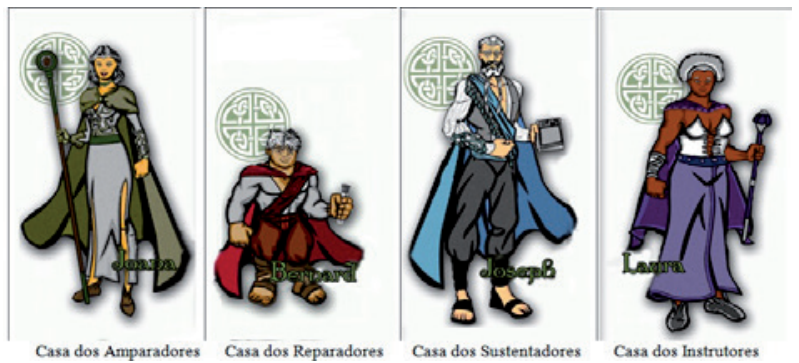

Figure 2 - Images of the Lords of each House

In addition to representing the characters who act in the plot, it also falls to the master to clarify the game's rules, to accompany the creation and performance of the characters, to undertake the narration, and to to conduct the problemsituations, the analysis and the validation of the actions undertaken by the players, as well as the judging of the consequences of these actions.

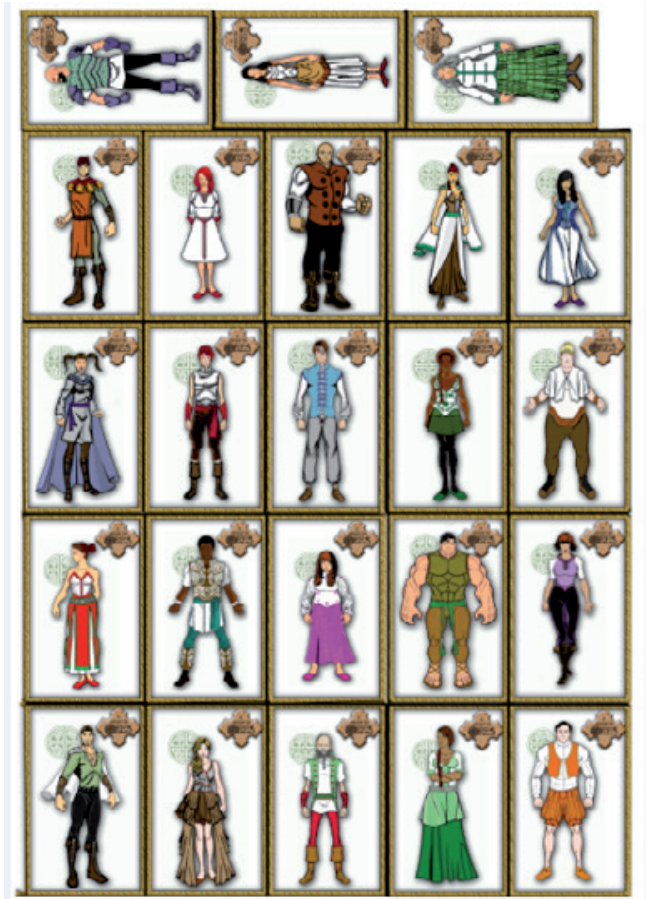

Figure 3 - Cards of characters available for the players
The player's profile is defined following the narration of the prologue by the master and the request to compose the character; to do so, the player must, first of all, choose from the 23 character cards available (Figure 3 ) which will visually represent him or her in all the games. These cards present images of characters of both sexes and with differing characteristics.

After selecting her image, the player must create a name, set an age and elaborate a brief history for her character, recording this information in the character's file (Figure 4). She must also select - on the previously-defined skills menu, available in the above-mentioned file - those skills which she considers most relevant to her character and to her good performance in the game.

This selection of skills occurs through the distribution of 10 points, which may be assigned to a single skill, if the player so wishes, or be distributed to two, three, or even ten skills. This means that the player cannot, in this phase of composing her file, go beyond the ten points permitted for the beginning of the game. These skills will be utilized for resolving the problem-situations experienced in each scenario.

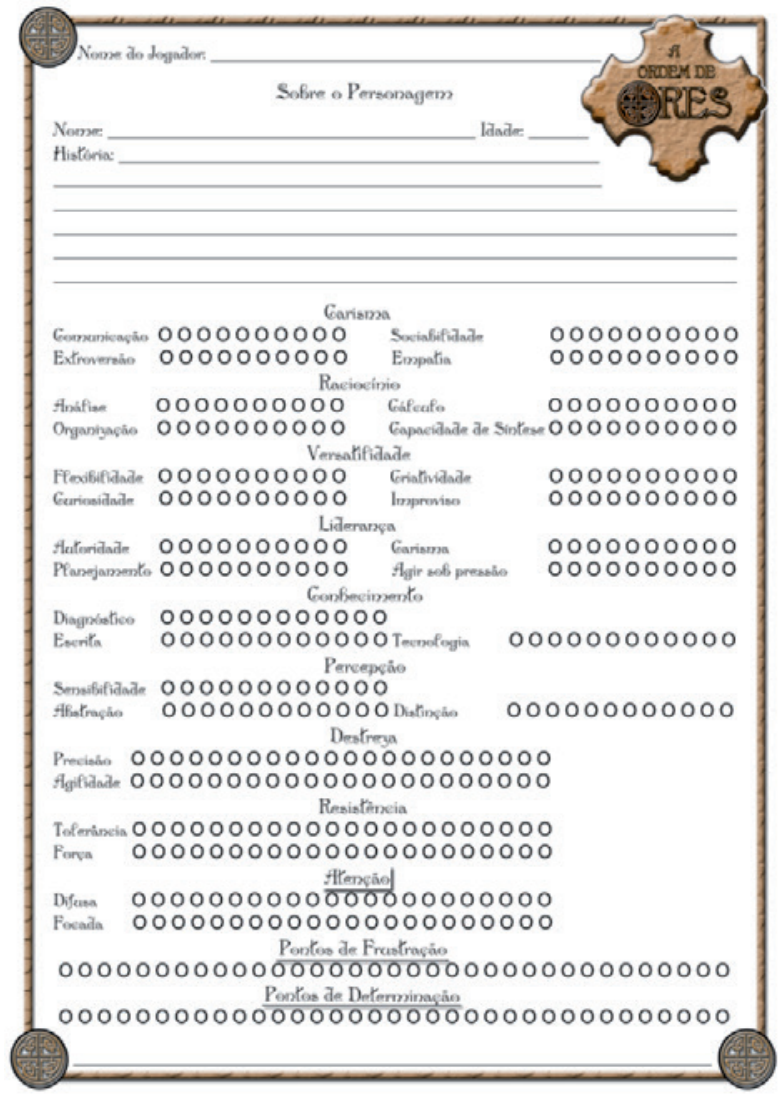

Figure 4 - The character's file 
The House of the Helpers, which corresponds to the apprentices' experience in the primary care scenario, is made up of eight problem-situations. The first situation encompasses the story of Thomas, which addresses domestic violence; the second, that of Claire, which deals with pregnancy in adolescence; the third addresses the case of Rose, a mother who seeks help for her son, a drug addict; the fourth situation refers to Elberto, the innkeeper, responsible for causing food poisoning in the population; the fifth depicts the invention of a wizard, who helps in the embracement in the House of the Helpers; the sixth deals with the need for undertaking an educational action with a group of volunteer workers; the seventh addresses the story of Mr. Ludo, who requires home care; and the eighth encompasses the case of Mistress Berta, who abandoned the treatment undertaken daily in one of the Houses of the Helpers. The main skills to be emphasized in this house, through the challenge-situations, were charisma, abstraction, perception and empathy.

The House of the Repairers allows the apprentices to experience the scenario of hospital care, and is made up of seven problem-situations. The first of these refers to a group of soldiers who, after falling into an ambush, require emergency treatment; the second is the story of Marrie, a prostitute who presents a vaginal hemorrhage after an abortion; the third addresses the need for treatment of a group of soldiers whose medication is unavailable and which needs to be substituted by another which is similar; the fourth mentions a female soldier who is a spy, who tries to convince the apprentices to help attend a group of the kingdom's enemies, leaving aside the care for the soldiers of the kingdom itself, wounded in an ambush; the fifth situation covers the case of Mr. Ducale, whose belief stops him from accepting treatment necessary for his survival; the sixth reveals the story of Jacob, a woodcutter who asks for assistance in the House of the Repairers; and the seventh concerns the care given to women in childbirth, for which it is necessary to seek and prepare the appropriate medications. The main skills emphasized here through the challenge-situations were dexterity, strength, resistance and agility.

The House of Supporters, which corresponds to the apprentices' experience in the management scenario, is made up of six problem-situations. The first is that of repairer Diana, who belittles a medication from the House's stock in order to avert the discovery of her failure to treat patients with a particular illness; the second addresses the story of King John Claymore, who needs a recently-discovered drug which would prolong his life, but which - at the same time - represents the cure of a child, who has the same disease; the third is about the dispute over materials among professionals from two hospital wards, who try to maintain the reserves of their stocks; the fourth depicts the need for change in the order of attendance undertaken in one of the Houses of the Repairers; the fifth covers the case of Moyra, who works in one of the Houses of the Helpers and mistreats people who go there seeking attendance; and the sixth covers the dispute between the repairers Leonel and Estéfano, who commit a great many errors in their activities and who sabotage each other's work. The main skills emphasized here in the challenge-situations are versatility, charisma, leadership and curiosity.

The House of the Instructors, which corresponds to the apprentices' experience in the scenario of education-research, is made up of three problem-situations. The first addresses the need for the apprentices to undertake, and hand in on time, a work which has not been finished by the team which was, until this point, responsible for this activity; the second corresponds to the case of Princess Sara, who needs to continue with her studies, but refuses to do so; the third situation is that of Oliver, a homeless man who falls in love with a woman who has a contagious, incurable disease, which both refuse to believe exists. The main skills to be emphasized in this house, through the challenge-situations, are reasoning, use of technology, knowledge and organization.

The players, during the experiencing of the problem-situations in each House in the game, collectively and orally construct strategies for resolving the problems identified. At the end of the experience in each House, the players undergo tests of specific skills for each scenario. One can cite, for example, one problem-situation experienced in the House of the Helpers, in which a test of communication skills is required. This test has a level of difficulty of six - previously established in the game - and each player will be successful in this test if he or she obtains a result of over six.

This result greater than six, in this case, will be calculated by the number of points which the player has in her file under 'tested skill' - in this case, communication - and through the value obtained from rolling dice. In the above example, the player will be successful if the sum of her points 
in the communication skills added to the value obtained by throwing dice is greater than six.

The score in the game is expressed in two ways: experience points and frustration points. The experience points are acquired through tests of skill undertaken for resolving problem-situations. In the test in question, when the player is successful, she gains two experience points, and even when unsuccessful, acquires one experience point. This type of point can be added to the character's file in any skill which the player chooses. The frustration points, on the other hand, are acquired through lack of success in the skill tests. In this case, the player, in addition to gaining one experience point, also acquires one frustration point. The frustration point, which will be recorded in the character's file, entails the subtraction of one point in the next skills test undertaken by him in the game.

\section{Evaluation of the game's dynamics with RPG players}

The prototype of the game was evaluated with 11 RPG players, in a single meeting, lasting for seven hours, in order to go through all the problem-situations, questions and considerations regarding the dynamics and understanding of the game. These players made up a group which was already accustomed to this process of testing RPG games, contributing in particular to analyzing the scoring system, the defining of the rules, and other issues inherent to the dynamics and playability of the game.

This meeting, moreover, involved the participation of professionals who are specialists in RPGs and the observation of the team of researchers, seeking to identify, in the progression of the game, the characters' engagement in the game's plot, the use of skills, and their distribution in the character's file; the understanding of the rules; and the interaction in the game.

The RPG players who participated in the evaluation were of both sexes (72.7\% male), aged between 19 and 26 years old (mean: 22.54; SD: 2.621 ), of whom $54.5 \%$ were in higher education, $18.2 \%$ had already graduated, $9.1 \%$ had technical training and $18.2 \%$ were not studying at the time. The participants' experience with RPGs was from seven months to ten years (mean: 5.6 years; SD: 3.32). It is noteworthy that the mean age of the participants in this evaluation is comparable to that observed among undergraduate students of
Nursing.

In this evaluation, it was possible to observe that the players did not have any difficulties in relation to understanding the rules and to their insertion in the plot, and showed satisfaction and understanding of the game's purpose. Based on the observation and records made in the evaluation, it was possible to redefine the level of difficulty of the tests of skills proposed in the game, and to make adjustments referent to playability and to the leading of the story. In relation to the leading of this, it was possible to note the importance of using a map (Figure 5) as a visual reference for identifying the different characters represented by the master and the scenarios in which the situations take place.

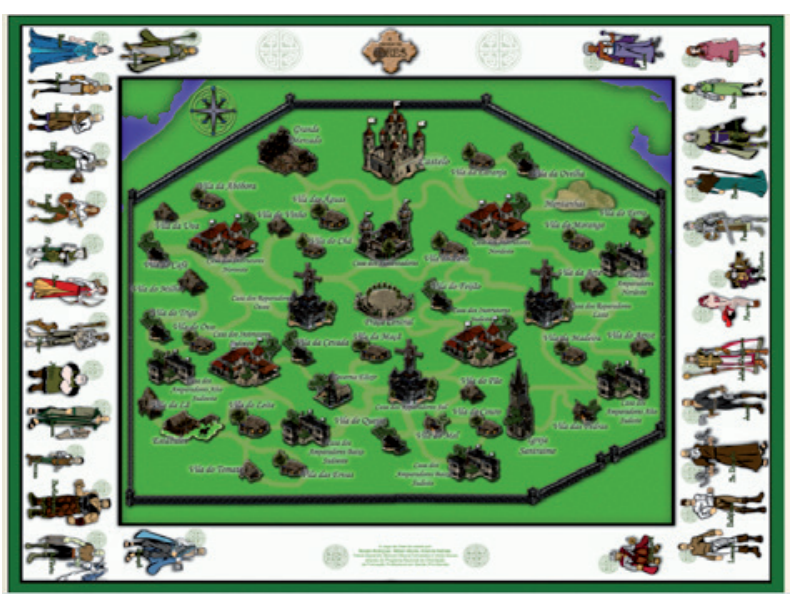

Figure 5 - Map of the game "The Order of Ores"

\section{Preparation of the masters}

The last stage of the process of creating the game was geared towards preparing the four masters who would act in the first experience of its application - one nurse, two psychologists and one scholar with a scientific initiation grant of the Undergraduate Course in Nursing. The preparation of the masters was undertaken by the RPG specialists, with the objective of ensuring safety in this first run-through of the game. During the preparation, the masters internalized the problem-situations of the game and its rules and discussed better strategies for guiding the situations and the game.

\section{The application of the RPG game in the undergraduate nursing course}

The game "The Order of Ores" has been administered in the Integration Seminar II course 
over three consecutive semesters. The course is offered entirely in the format of the RPG game, being run in a total of six sessions of rounds, each one lasting 120 minutes for experiencing the problem-situations in each one of the four contexts addressed in the game - primary care, hospital care, management and education.

Following each session of the game, a period for discussion between students and a professor with expertise in the context addressed that day took place, with a view to analyzing the problem-situations experienced, the discussion on the skills required, and the implications of these in the training process. For this meeting, it is proposed to the students to first read an article which assists in reflecting on the work process in relation to the context to be addressed that day. In this debate, aspects considered more polemic, relevant, facilitative and hindering in resolving the problems are also referred to, as well as the correlation with the situations experienced with the nurse's practice. The objective, in this case, is to encourage the students to construct knowledge and meanings of the professional activities in the main scenarios of Nursing work.

The selection of the masters takes place on the first day of class, among students of the first group or among those who have already acted as masters in previous semesters. The criteria for selection occurs through the interest of the student and through ability acting in leading the game, sometimes resulting from previous experiences as RPG players. The students selected undergo a training stage and progress, monitored by the course's professors, throughout all the games, after which each master's way of acting, and the possibilities for resolving the difficulties identified, are discussed. Each master is responsible for being the master for the same group from the first to the last round. On the first day of class, prior to the first session of the game, a meeting is held with the masters in order to present and discuss with them the problem-situations, the rules, and the game's dynamics.

The experience of using the RPG as a pedagogical strategy in the undergraduate course in Nursing has shown that the game created constitutes a non-traditional and ludic strategy which promotes for the students the process of becoming closer to professional practice, active participation in the learning experience, self-reflection and reflection on the training and the future professional practice. $^{17}$

\section{FINAL CONSIDERATIONS}

It is believed that the game developed constitutes a pedagogical strategy in which the students become involved and are engaged in their process of thinking, of developing new meanings, of knowing, and of acting.

In proposing the metaphorical experience of problem-situations which belong to the professional routine of the nurse, the game makes it possible for students to test, simulate and (re-)create imaginary scenarios, promoting the development of autonomy and of critical-reflexive thinking in relation to the training and the future professional practice.

\section{REFERENCES}

1. Silva MG, Fernandes JD, Teixeira GAS, Silva RMO. Processo de formação da(o) enfermeira(o) na contemporaneidade: desafios e perspectivas. Texto Contexto Enferm. 2010 Jan-Mar; 19(1):176-84.

2. Sobral FR, Campos CJG. Utilização de metodologia ativa no ensino e assistência de enfermagem na produção nacional: revisão integrativa. Rev Esc Enferm USP. 2012 Fev; 46(1):208-18.

3. Moura ECM, Mesquita LFC. Estratégias de ensinoaprendizagem na percepção de graduandos de enfermagem. Rev Bras Enferm. 2010 Set-Out; 63(5):793-8.

4. Huizinga J. Homo ludens. $5^{\mathrm{a}}$ ed. São Paulo (SP): Perspectiva; 2010.

5. Pires MRGM, Guilhem D, Göttems LBD. Jogo (IN) DICA-SUS: estratégia lúdica na aprendizagem sobre o Sistema Único de Saúde. Texto Contexto Enferm [online]. 2013 Abr-Jun [acesso 2014 Mar 06]; 22(2) 379-88. Disponível em: http:/ /www.scielo.br/pdf/ tce/v22n2/v22n2a14

6. Petsche J. Engage and excite students with educational games. KQ. 2011 Sep-Oct; 40(1):42-4.

7. Prinsen G, Overton J. Policy, personalities and pedagogy: the use of simulation games to teach and learn about development policy. J Geogr Higher Educ. 2011; 35(2):281-97.

8. Rosenthal MS. Name that contraceptive! A game for the human sexuality classroom. Am J Sex Educ. 2010; 5(2):189-99.

9. Chanes M, Leite MMJ. Mensuração de conhecimento adquirido por meio de jogo lúdico de liderança. Nursing. 2008; 10(117):70-4.

10. Schmit WL. RPG e educação: alguns apontamentos teóricos [dissertação]. Londrina (PR): Universidade Estadual de Londrina, Programa de Pós-Graduação em Educação; 2008.

11. Rosa M. Electronic and online RPG in the mathematics education context. JIEEM. 2010; 2(1):111-37. 
12. Simpson JM, Elias VL. Choices and chances: the sociology role-playing game - the sociological imagination in practice. Teach Sociol. 2011; 39(1):42-56.

13. Oliveira Neto AA, Benite-Ribeiro AS. Um modelo de Role Playing Game (RPG) para o ensino dos processos da digestão. Itinerarius Reflectionis. 2012; 2(3):1-15.

14. Aragão RML. Role Playing Games no ensino do marketing: uma experiência com o RPG didático. Reveduc. 2009; 3(1):162-75.

15. Minayo MCS. O desafio do conhecimento: pesquisa qualitativa em saúde. $11^{\text {a }}$ ed. São Paulo (SP): Hucitec, 2008.
16. Ministério da Saúde (BR), Conseho Nacional de Saúde, Comissão Nacional de Ética em Pesquisa. Resolução N $^{\circ} 196$ de 10 de outubro de 1996: diretrizes e normas regulamentadores de pesquisa envolvendo seres humanos. Brasília (DF): MS; 1996.

17. Soares AN. Role Playing Game (RPG): elaboração e avaliação de estratégia pedagógica para formação crítica e autônoma do enfermeiro [dissertação]. Belo Horizonte (MG): Universidade Federal de Minas Gerais, Programa de Pós-Graduação em Enfermagem; 2013. 